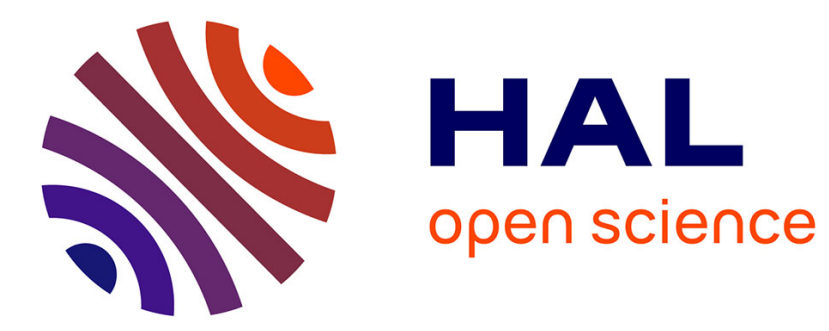

\title{
Diversity in linguistic representations
}

Catherine Fuchs

\section{To cite this version:}

Catherine Fuchs. Diversity in linguistic representations: a challenge for cognition. C. Fuchs and S. Robert. Language Diversity and Cognitive Representations, Benjamins, 1999. halshs-00067929

\section{HAL Id: halshs-00067929 \\ https://shs.hal.science/halshs-00067929}

Submitted on 9 May 2006

HAL is a multi-disciplinary open access archive for the deposit and dissemination of scientific research documents, whether they are published or not. The documents may come from teaching and research institutions in France or abroad, or from public or private research centers.
L'archive ouverte pluridisciplinaire HAL, est destinée au dépôt et à la diffusion de documents scientifiques de niveau recherche, publiés ou non, émanant des établissements d'enseignement et de recherche français ou étrangers, des laboratoires publics ou privés. 
Communication au Colloque international

«Diversité des langues et représentations cognitives »

(ENS, Paris, 1996)

Parue en 1999 dans les Actes

Language Diversity and Cognitive Representations (C. Fuchs \& S. Robert, eds.), Amsterdam : Benjamins

(Preliminary Version)

\title{
DIVERSITY IN LINGUISTIC REPRESENTATIONS :
}

\author{
A CHALLENGE FOR COGNITION
}

Catherine FUCHS

CNRS : ENS-Paris

\section{Language and languages : unity and diversity}

Language diversity is a subject which has long been side-stepped in scholarly work on language, the verbal faculty. At best, any discussions have been purposely restricted to considerations of superficial syntactic variation. In recent years, however, cognitive science has shown renewed interest in this subject, in connection with the diversity of the meaning representations constructed in individual languages.

\subsection{A subject mostly side-stepped...}

As one of the characteristic properties of the human species, the language faculty is inevitably of central importance to cognitive science. Speech activity involves various mental processes which are of interest to the psychologist as student of individual linguistic behavior and the ways in which children acquire language. The use of language relies on neural circuits within the brain, whose operation is described by the neurophysiologist, particularly through the observation of language pathology. Finally, speech output can be modelized, or even simulated, for the purposes of automatic processing, by the mathematician, the logician, or the information sciencist working on the formal aspects of artificial intelligence.

Language is thus central to all the primary disciplines involved in cognitive science. Now it happens that all these disciplines, particularly when lumped together under somewhat equivocal compound appelations such as 'psycholinguistics', 'neurolinguistics', or 'linguistic information science' (see Fuchs 1993), claim to be 
dealing with language in itself, sometimes even using the term 'natural language' to refer to this faculty of the human species, rather than to any particular spoken language. Language as such can, of course, only be apprehended through some individual language, for which reason scholars in these disciplines always apply themselves to a given language, usually their mother tongue (thus mostly English, but French for work done in France). But with the exception of a few studies, most of them fairly recent, which are avowedly contrastive (concerning acquisition or pathology in different languages, or in some cases, observation of the performance of multilingual subjects), most work on language as a cognitive activity are based on a single language. Even more surprisingly, the language in question is not considered in terms of its own distinctive features with respect to other languages ; rather, it is treated as some arbitrary representative of language in general. The ambiguity of the word language in English, which may stand either for the language faculty (cf. French word "langage") or for any individual language (cf. French word "langue"), has certainly helped to sustain this confusion.

The theoretical and methodological difficulties involved in contrastive work on more than one language are doubtless responsible for the fact that the study of speech activity is usually confined to a single language, a task hard enough in itself. All the same, it is easy to see how risky it is that taking any given language as representative may lead to unwarranted generalizations, first from that language to languages in general, then from all languages to the language faculty itself.

\section{2. ...or with discussions purposely restricted}

For the linguist, however, language diversity is an inescapable everyday fact. It is thus no surprise that one of best-known linguistic theories among cognitive scientists, Chomsky's generative grammar, comes directly to grips with this issue. What Chomsky and Lasnik (1993) call 'universal grammar' is a theory applying to syntax alone and postulating the existence of a set of universal innate principles (rules independent of any individual language) and a finite number of parameters which may vary within a limited range of values from one language to another. The purpose of the ongoing 'minimalist' program (Chomsky 1995) is to state the rules of universal grammar in an ever more unified and simplified way, justifying the description of this program by Epstein et al. (1996:3) as "counter-intuitively postulating that there is, in effect, only one human language despite the appearance of unlimited diversity".

This strong hypothesis postulating a universal grammar thus allows the subject of language diversity to be circumscribed in two ways: first of all, only the field of syntax need be considered; and secondly, only a small range of formal variations need be mapped onto universal principles :

Thus cross-linguistic variation, as expressed by parameters, is assumed to be highly restricted. A recent even more circumscribed theory of the formal properties of parameters postulates that each parameter is expressible as an irreducible cross-linguistic difference in the value of (a circumscribed set of) morphological features associated with certain lexical categories - the so-called functional syntactic categories such as Inflection/Agreement, Complementizer, and Determiner (S. Epstein \& al. $1996: 3$ ). 
The purpose of this theory is thus to show that, outside this extremely limited sort of parametric variation, actually involving only morphosyntactic features, individual languages would, as Chomsky himself says (1993:3), use "a single computational (syntactic) system and a single lexicon".

This attempt to keep interlinguistic variation to a minimum stems from the fundamental postulates of Chomsky's theory, particularly the hypothesis of a central, autonomous syntactic module which, as terms such as 'generation' and 'free monoid' suggest, can be described in terms of operations on logical or algebraic symbols, without regard to meaning and use in context. This module is then assigned, as an adjunct, a semantic component of the purely interpretative kind associated with formal languages, and presumably a pragmatic component as well, to account for the relations between the linguistic system and its users.

The assumption of a homology between natural language and formal language, deriving historically from the development of mathematical language theory (see work by Schützenberger, as well as Gross and Lentin 1967) has led to the widespread use of formal approaches to syntax. It should, however, be remembered that most studies from this perspective, particularly for purposes of automatic processing, have involved only the most widely spoken languages, with the result that, for many years, the issue of language diversity has been relegated to secondary importance.

The modular approach, which has been popularized in linguistics by generative grammar, has also been adapted to psychology (see for example Fodor 1983, who postulates the existence of a specific language module which is autonomous with respect to other cognitive activities) and to automatic language processing (particularly in systems with an architecture in the form of hierarchical layers, see Fuchs et al. 1993 : 26). Clearly, the success of the modular approach is largely due to the operative nature of the calculations it allows. Linguistics can thereby be truely accounted a calculus.

\subsection{A tradition long overlooked...}

Outside generative grammar, of course, the subject of language diversity has often been a subject of concern and debate among linguists involved in language description, particularly those working with languages with structures and typological features quite unlike their own native tongues. Descriptions are conducted with maximal methodological precaution: each linguistic system is treated in and for itself, and the postulation of universal categories and structures is carefully avoided, there being no $a$ priori reason for restricting the range of possible interlinguistic variations. Martinet ([1960] $1964: 25$ ) sums up this approach in the following terms: 
We may reserve the term 'language' for a doubly articulated, verbal instrument of communication...There is nothing outside this common denominator which cannot vary from language to language. 1

In earlier times at least, descriptive studies were carried out within a structuralist framework. As opposed to generative grammar, they have in common the tendency to stress the way languages differ. Each language is viewed as a unique system of contrasting signs, thus implying that the way the sound-meaning relationship is organized, and hence the way reality itself is categorized, may vary from language to language. Each language therefore dictates to its speakers what they can say, i.e., the set of meaningful linguistic patterns. As Hockett (1954:116) puts it, interlinguistic difference consists less in "what it is possible to specify" than in "what it is relatively easy or hard to specify". From the ethnolinguistic standpoint, with which language description often merges, language diversity parallels cultural diversity.

There are many reasons for cognitive science having largely ignored this descriptive tradition. Some are institutional and need not concern us here. Others, however, are theoretical in nature and so are of direct interest. Firstly, there are difficulties with descriptions which look to be too locally targeted and exempt of wider perspectives, or too fine-grained, with data so complex as to discourage any attempt at formalization. In either case, they appear unwieldy. Another obstacle is created by descriptivist rejection of universalism and exclusive attention to differences, perhaps even belief in the irreducible nature of these differences, which may suggest that descriptive linguistics is for collector types who are attracted more by curios than by generalization, as well as contradicting the intuitive impression that there must be a common underlying ground to account for phenomena of language switching (translation and multilingualism) and acquisition.

\section{4. ...and now strangely back in fashion}

Nevertheless, one of the pendulum movements which are so common in history now seems to be bringing reawakened interest in language diversity within cognitive science after years of indifference. Symptomatic of this peculiar revival, which is doubtless attributable more to a realignment of certain theoretical issues in the field of cognition than to any specific concern for linguistic phenomena in themselves, is the rehabilitation over the past few years of B. L. Whorf (1897-1941), an ethnolinguist who specialized in Native American languages. His work is currently the object of a sympathetic reappraisal, after having been denounced for many years as 'psychologistic' and even racist, even though he explicitly distanced himself from notions such as LevyBruhl's 'primitive mentality'. Several 'neo-Whorfian' meetings have been held, where the relations between linguistics, culture, and thought have been reexamined in the light of Whorf's ideas. Likewise, a number of publications have recently been devoted to him, including in the current decade alone Schultz (1990), Lucy (1992), Joseph (1996), and particularly Lee (1996), who draws on both published and unpublished sources to paint

$1 "(\ldots)$ nous réservons le terme de langue pour désigner un instrument de communication doublement articulé et de manifestation vocale (...) hors cette base commune, rien n'est proprement linguistique qui ne puisse différer d'une langue à une autre". 
him as a pioneer whose daring views on the role of language in cognition are largely to blame for the misunderstanding and hostility directed at him by his contemporaries and by succeeding generations.

Despite Lee's evident bias in Whorf's favor, which at times leads her to find more in his thought than may be there, her work is relevant in two ways : first of all, she shows that the so-called 'Sapir-Whorf hypothesis' of linguistic relativism is not reducible to the caricatures that have often been made of it in the literature ; secondly, she points out the profound theoretical affinities between Whorf's approach and a number of established positions in other disciplines.

A few words are now in order concerning 'linguistic relativism'. For Whorf, linguistic processes stem from cognitive operations located at the core of human conceptual activity. But these processes do not operate arbitrarily on undifferentiated experience data. They are rather secondary elaborations working up data which are already perceptually structured, and which provide a common basis for reference. There are thus universal configurations of experience, to which linguistic patterns of classification and categorization apply in varying ways. Whorf thus distinguishes 'isolates of experience' (abstracted from sense data already worked up on the interface between the organism and its environment on the basis of invariant biological processes) and 'isolates of meaning' (those features of experience which are involved in meaning construction and may be either socially and culturally acquired or purely personal). Meaning construction thus comes down to a selective abstraction from experience of certain salient or coherent patterns. In other words, the material for linguistic expression is an already structured reality, framed according to psychophysiological patterns which are identical for all mankind, though languages may conceptualize these data of experience differently in accordance with differences in culture. Ultimately then, a language can only build up its own particular 'world view' insofar as the community of its speakers chooses isolates of experience in a distinctive way and invests them with a common meaning.

On this view, linguistic relativism is not a kind of philosophical skepticism which sees each language community as locked into its own irreducibly specific world view ("each language tells its own truth, i.e., has its own conception of the world"). It is rather more like the principle of relativity in physics, whereby the observer's position in space determines his view of a given object ("each language looks at reality from its own standpoint"). The following two passages from Whorf tend to support this understanding of him as holding that interlinguistic variations are like differences in the projection of a system of coordinates of observation on an invariant background of experience of the world :

We are thus introduced to a new principle of relativity, which holds that all observers are not led by the same physical evidence to the same picture of the universe, unless their linguistic backgrounds are similar, or can in some way be calibrated ([1940a] $1956: 214$ ).

(...) users of markedly different grammars are pointed by their grammars toward different types of observations and different evaluations of externally similar acts of observation, and hence are not equivalent as observers but must arrive at somewhat different views of the world ([1940b] $1956: 221)$. 
An explicit statement of the same idea can already be found in Sapir (1924:153):

The world of linguistic forms, held within the framework of a given language, is a complete system of reference, very much as a number system is a complete system of quantitative reference or as a set of geometrical axes of coordinates is a complete system of reference to all points of a given space. The mathematical analogy is by no means as fanciful as it appears to be. To pass from one language to another is psychologically parallel to passing from one geometrical system to another. The environing world which is referred to is the same for either language ; the world of points is the same in either frame of reference. But the formal method of approach to the expressed item of experience, as to the given point of space, is so different that the resulting feeling of orientation can be the same neither in the two languages nor in the two frames of reference. Entirely distinct, or at least measurably distinct, formal adjustments have to be made and these differences have their psychological correlates.

'Configurational linguistics', as Whorf himself called the theory he set out to develop, seems to have been influenced by the methods of physics and chemistry. Linguistic units are not thought of as stable, preexisting components which can be conjoined without effect in linear or sequential relationships, but rather as relatively indeterminate entities which can be structured according to the relational patterns in which they appear, a view reminiscent of the way in which modern physics rejects the mechanistic approach of classical physics. Likewise, linguistic structures are treated in terms of merger, fluidity, and dispersion, notions associated more with chemical processes than with logical calculus. Whorf himself explicitly invokes the parallel with the physical sciences :

The mathematical sciences require exact measurement, but what linguistics require is, rather, exact 'patternment' - an exactness of relation irrespective of dimension (...) linguistics has developed techniques which, like compasses, enable it without any true measurement at all to specify exactly the patterns with which it is concerned. Or I might perhaps liken the case with the state of affairs within the atom, where also entities appear to alternate from configuration to configuration rather than to move in terms of measurable position. As alternants, quantum phenomena must be treated by a method of analysis that substitutes a point in a pattern under a set of conditions for a point in a pattern under another set of conditions - a method similar to that used in analysis of linguistic phenomena ([1940b]; $1956: 231)$.

As Lee consistently stresses, this holistic, dynamic, relational approach to patterned meaning construction has resonances in both Gestalt psychology and the connectionist theory of neural networks.

The renewed interest in Whorf's theory in the field of cognition is definitely no accident. Equally symptomatic is the fact that this well-organized reappraisal is associated with references to certain contemporary linguistic theories, in particular to the American school of cognitive grammar whose links with Gestalt theory and connectionism have also been repeatedly pointed out (though to some minds, these grammars seem more concerned with relatively static mental structures than with truly dynamic processes, cf. Nuyts $1996: 154-5)$. Indeed, 'cognitive linguistics' shifts attention from pure syntax to the domain of semantics and conceptualization, whence 
the primacy assigned to metaphor as a linguistic phenomenon (represented by notions such as 'fictive movement', 'mental spaces', and so forth), and the attention devoted to describing the linguistic representation of conceptual fields such as time, space, deixis, etc., in terms of very general underlying cognitive structures of language (cf. work by Langacker, Lakoff, and Talmy). It may be noted in passing that cognitive grammars have numerous points in common with various less internationally renowned European linguistic theories, such as Culioli's (1990) 'utterance-based' (situational) approach or to some extent Guillaume's (1969) psychomechanical theory of language, both of which share some of the theoretical assumptions cited above.

\section{Variation and invariance}

The diversity of the ways in which languages represent reality is a core issue for linguistics, demanding a theoretical basis for linking variation and invariance. Analogous situations exist in other scientific disciplines, e.g., biology where the phenotype/genotype articulation is crucial. The issue is equally important to cognitive science : the overall view of how language, thought, and cognition are related intimately depends on how variation and invariance are apprehended.

\subsection{The range of variation}

The way in which the linkage between language to thought is theoretically expressed is decisive for the view taken of the nature and importance of crosslinguistic variation in the construction of representations.

'Computational' approaches conceive of language and thought as two autonomous modules, each carrying on its own computational processes. In the words of Jackendoff (1996),

Thought is a mental function completely separate from language and can go on in the absence of language" (p. 2) ; Although language expresses thought, thought itself is a separate brain phenomenon (p. 8) ; Language is just a vehicle for externalizing thoughts, it isn't the thoughts themselves (p. 19).

Various scholars using this modular, computational approach (cf. for example, Pinker 1994) would say that understanding a linguistic message consists of transforming sequences of words, ordered differently in each language, into syntactic arborescences, then interpreting the resulting trees as language-independent formulae of logical semantics (Fodor's 1975 'universal language of thought'). The mind, as it were, goes through a zone of formal variation before reaching the terra firma of universal conceptual semantics. Interlinguistic differences thus have no bearing on thought itself :

Thinking is largely independent of what language one happens to think in. A French speaker or a Turkish speaker can have essentially the same thoughts as an English speaker can they're just in French or Turkish (...). If different languages can express the same thought, then thoughts can be embalmed in the form of any single language : they must be neutral as to what language they are to be expressed in (Jackendoff $1996: 6$ ). 
In this passage, the word essentially is vital to the reasoning. Indeed, Jackendoff appends the following note (note 2, p. 31) :

I say essentially here in order to hedge on possible 'whorfian' effects. There are undoubtedly expressive differences among languages in vocabulary, as well as in grammatically necessary elements such as tense-aspect systems and markers of social status (...) such differences must not be blown out of proportion; they are decidedly second- or third-order effects (...). They may create difficulties for literary translation, where style and associative richness are at stake, but no one seriously questions the possibility of effectively translating newspapers and the like.

This reference to 'expressive differences' as 'second-order' means that interlinguistic variation can only affect a minor aspect of thought, i.e., stylistic connotation, while denotative or referential meaning remains invariant to assure the possibility of translating informational content. Other writers in the same volume reject this view, cf. Barden's (1996 : 66-7) remark :

If different languages can express the same thought, the thought cannot be embalmed in the form of any single language (...). As soon as you allow that the thoughts might not be exactly the same, you open the door to the possibility that each of the thoughts is indeed embalmed in the form of a particular language.

Barden's reaction is typical of what might be called 'representational' (as opposed to computational) approaches to language, whereby language is seen as primarily a means of representation of reality and intersubjective communication. These approaches tend to link language to thought by postulating a kind of 'thought language' inherent in all individual languages, while not excluding the possibility of extralinguistic thought. All this is implicit in the Benveniste's ([1958] 1966 : 70) particularly Whorfian remark :

The sayable defines and organizes the thinkable. The speaker's language provides him with the basic configuration of the properties his mind attributes to things ${ }^{2}$.

From the representational standpoint, understanding a linguistic message would rather be conceived as a dynamic process of meaning construction by the participants, using the meaningful patterns peculiar to a given language, which therefore vary from one language to another.

Philosophically speaking, computational and representational approaches fit into different theoretical paradigms. The former belong to the current paradigm of reference in cognitive science, the so-called 'cognitivist' paradigm which uses the computational model of mind (and the brain, conceived of as a mere processing device for symbols, see Jackendoff 1987, and more recently, Pinker 1994). This model has, of course, given rise to considerable controversy over the years, cf. Searle's (1992) criticisms on philosophical grounds and Edelman's (1992) objections from the standpoint of neurobiology.

2 "C'est ce qu'on peut dire qui délimite et organise ce que l'on peut penser. La langue fournit la configuration fondamentale des propriétés reconnues par l'esprit aux choses". 
As for representational approaches, it must be admitted that there is currently no real alternative paradigm under which they might be subsumed. There are nevertheless various signs that such a paradigm, which has been tentatively labeled 'constructivist', is in the making. It would involve rejecting the idea that language should be treated as one or more specific, autonomous modules, and thinking of it rather as a property which emerges from the general mechanisms of cognition and has numerous homologous relationships with other cognitive activities including perception. The notion of computation is thus replaced by the idea of a process of construction of emerging, more or less salient, typical, and stable meaningful forms. Likewise, its formal apparatus of modelization must be sought, not within algebraic logic, but in dynamic topology.

\subsection{From universals to invariant features}

However much language-specific representations may vary, they are never irreducibly specific since language switching is always a possibility. One could therefore reasonably expect to be able to define certain crosslinguistic universals of representation.

Translatability is often cited as proof of the existence of such universals. For those who hold a computational view of language, the language-extrinsic universality of thought accounts, as we have seen, for the possibility of translation :

The point of translation between languages is to preserve the thought behind the expression (Jackendoff $1996: 6$ ).

Thought universals thus provide the common semantic and conceptual foundation for certain secondary variations deriving from differing forms of expression. The process of translation must then consist of eliminating superficial differences in order to reach the hard core which provides the standard of reference. This comes down to establishing an equivalence relation in the guise of retention of a common informational content pace minor variations.

From a representational viewpoint, however, the actual possibility of translation, i. e., of constructing equivalences by transposition from one language to another, does not in itself constitute an argument for the existence of transcendent thought universals ready-made for use by individual languages. Many authors make the point that languages are not nomenclatures or stocks of labels for designating realia, nor are the vocabularies of individual languages sets of terms for expressing a universal $a$ priori system of concepts. What is true of words goes for sentences as well, i.e., syntactic structures cannot be univocally interpreted in terms of universal logical formulae. In other words, any comparison or transposition of these structures can function simply on the basis of a given number of analogical properties and in no way requires the assumption of a common extrinsic content.

Contrastive studies of utterance organization in different languages have shown how each one uses its own lexical and morphosyntactic resources to build specific meaning patterns involving different pragmatic schemes of orientation, i.e., different 
layouts of reality. If changing languages is indeed like adopting a new layout (as the quotations from Sapir and Whorf above suggest), then the very conceptualization of the referents must itself change, and the postulated equivalence must be seen in a dynamic perspective, somewhat as geometry apprehends invariance in the course of spatial transformations of figures (by rotation, translation, or symmetry).

One might even venture an analogy with automatic translation by contrasting the so-called 'pivotal systems', which seek underlying language-independent semantic and conceptual representations, with 'transfer systems', which have the more modest and realistic aim of constructing crossover rules for the semantic representations associated with texts in each language (Fuchs et al. 1993 : 206-9).

Obviously, the theoretical issues of language-to-language translation can be correlated, mutatis mutandis, with those of paraphrase within a single language. Forms of expression which differ across languages have their correlates in the variety of specific semantic representations constructed by a given language, representations which cannot be reduced to a single logical formula capturing precisely the intersection which provides a common core for measuring difference in terms of quantitative distance. Here again, dynamic equivalences and qualitative differences are involved (see Fuchs 1994a).

This outlook replaces the notion of statically conceived substantive universals with that of operative universals, or functional invariants, to be viewed in dynamic terms. This would mean that languages construct meaning by an interplay of markers (not just lexical items, but grammatical elements and syntactic structures as well) which are operators issuing instructions for the elaboration of meaning configurations or patterns, rather than symbols with substantive content.

\subsection{In search of invariants}

The search for crosslinguistic invariance in representations has, for many years, been the objective of typological comparative studies. These include Greenberg's work in syntax (particularly his 1963 paper and his 1966 work on constituant order and feature hierarchy, where he sets forth the notion of 'implicational universals', for which Vennemann proposed a 1972 generalization in terms of correlations) and Comrie's $(1976,1985$, see also 1981) work on tense and aspect systems. Mention should also be made of the work done by the UNITYP group at the University of Cologne under the direction of H. Seiler (Seiler and Brettschneider 1985, Seiler 1994), and by G. Lazard's group in Paris, whose results have appeared in the house journal Actances. This trend is currently very much in vogue at the international level, as is shown by the creation in 1994 of the Association for Linguistic Typology and the appearance in 1997 of the first issue of Linguistic Typology under the Associations's auspices.

The typological approach contrasts with the hypothesis-and-deduction approach of generative grammar. It is inductive and tries to generalize from observation and comparison of the largest possible sampling of languages (Greenberg 1973, 1974). It also applies equally to lexical and to grammatical markers (Lazard 1981). 
Typologists make no assumption as to the existence of universal grammatical categories, but rather start from the fact of variation and look for invariants at the most abstract level of the very processes of category construction, i.e., grammaticalization mechanisms. To quote Lazard (1992: 431-2) :

Rather than crosslinguistic 'categories', there would seem to be invariant notions around which the categories of individual languages tend to take form (...) This means that, if we conceive the set of possible notions as located in a multidimensional space, 1) some regions of this conceptual space are such that perhaps all, in any case most, languages construct grammatical tools there (...);2) some parts of the regions which act as 'fields of grammaticalization' have preferential status, i.e., are 'focal zones'. The notions found there are much more frequently grammaticalized than others in the same field. Many languages thus have forms whose range of meaning contains one or more of these focal zones; but the extent and shape of this range will vary with the language, i.e., will include a given number of neighboring notions in addition to the primary one (italics added) ${ }^{3}$.

This implies the existence of invariants at the level of both the field of grammaticalization and the focal zone. Nevertheless,

each language marks out its grammatical categories in each field. The outlines vary since they are peculiar to each individual language, but the categories frequently include one or more focal zones (ibid.) $)^{4}$.

As this quotation shows, the search for invariants underlying grammatical markers has all the characteristic features of constructivist approaches to language : rejection of substantive universals, definition of dynamic invariant features, representation of meaning in terms of multidimensional space, and dynamic construction of salient patterns. The notions of 'taking form' and 'focal zone' are symptomatic in this sense, though Lazard wants to avoid defining them too strictly :

Semantic substance is continuous and unstable. Differences within it are gradual. Focal zones probably exercise a variable force of attraction, i.e., the notions they contain have a varying propensity to grammaticalization (ibid., italics added) ${ }^{5}$.

\footnotetext{
3 "il existerait non pas, à proprement parler, des "catégories" interlangagières, mais des notions invariantes autour desquelles les catégories des langues particulières, en quelque sorte, se cristalliseraient préférentiellement (...). (Cela) signifie, si nous nous représentons l'ensemble des notions possibles comme situées dans un espace multidimensionnel : $1^{\circ}$ ) que certaines portions de cet espace sémantique sont telles que toutes les langues peut-être, beaucoup de langues en tout cas, y construisent des instruments grammaticaux (...) ; $2^{\circ}$ ) que, dans ces portions d'espace que sont ces "domaines de grammaticalisation", certaines régions sont privilégiées : ce sont les "zones focales". Les notions qui y sont situées sont beaucoup plus fréquemment grammaticalisées que d'autres du même domaine. Beaucoup de langues ont donc des formes dont l'aire (ou mieux : le volume) de signification contient l'une ou l'autre de ces zones focales, mais cette aire (ou ce volume) a une extension et une forme variables selon les langues, c'est-à-dire comprend, outre la notion privilégiée, telles ou telles des notions voisines"

4 "chaque langue découpe dans chaque domaine ses catégories grammaticales; ce découpage est variable, car il est propre à chaque langue ; mais il est fréquent que les catégories recouvrent ou englobent l'une ou l'autre des zones focales"
} 
Notions of 'gradualness' and 'continuity' are important here as being characteristic of much recent work in the constructivist tendency (Fuchs and Victorri eds.1994). They are terms which capture an essential property of natural-language semantics, viz., the deformability of meaning patterns to allow the 'deployment' of meaning, particularly evident in polysemy, a phenomenon which is massively attested in every known language and best handled by a dynamic approach (Fuchs 1994b). This is what motivates research into the underlying operative invariants of polysemic markers whose meaning varies in context (Victorri 1996). Notions of gradualness are essential to semantics where absolute constraints of the all-or-nothing variety are rare, but many relative constraints, i.e., the results of the interaction of many differently-weighted parameters which bend the meaning in different directions, and shift it gradually or sometimes abruptly, must be accounted for. This is why topologically dynamic tools are needed, algebraic tools having showed themselves inadequate for modelizing such situations whenever there are intermediate cases in continua or regularities which cannot be stated as rules.

\section{Conclusion}

It should by now be clear that the search for interlinguistic invariance and the search for invariants underlying semantic variation within a single language (both synchronically and diachronically) are equally reliant on an understanding of gradualness. They therefore require identical treatment at the level of theory and modelization, particularly in the form of tools which can go beyond binary oppositions and all-or-nothing conceptualizations, whence the usefulness of topologically dynamic types of modelization.

Allowing for gradualness means recognizing that all languages are by nature such that the relationship between form and meaning is subject to constant readjustments and that there is no ultimate state of equilibrium. Some states are nevertheless more stable than others. These states can be modelized by approximation in a static, discrete way using classic algebraic tools. The stability of apparently fixed patterns can, however, only be explained on the basis of an underlying mobility.

\section{References}

Actances (revue du groupe RIVALC), Paris : CNRS.

Barnden, J. 1996. Unconscious gaps in Jackendoff's "How language helps us think". Pragmatics and cognition, $4: 1$, Amsterdam : Benjamins, pp. 65-80.

Benveniste, E. 1958. Catégories de pensée et catégories de langue. Les études philosophiques. Repris dans E. Benveniste. 1966. Problèmes de linguistique générale, Paris : Gallimard, chapitre VI, pp. 63-74.

\footnotetext{
5 "La matière sémantique est continue et mouvante, et les différences y sont graduelles. Les "zones focales" ont probablement une force d'attraction variable, c'est-à-dire que les notions qui s'y trouvent ont plus ou moins de propension à être grammaticalisées"
} 
Chomsky, N. 1993. A minimalist program for linguistic theory. In K. Hale \& S. Keyser (eds.), The view from Building 20 : essays in linguistics in honor of Sylvain Bromberger, Cambridge Mass. : MIT Press, pp. 1-52.

Chomsky, N. 1995. The minimalist program, Cambridge Mass. : MIT Press.

Chomsky, N. \& H. Lasnik. 1993. Principles and parameters theory. In J. Jacobs \& al. (eds.), Syntax : an international handbook of contemporary research, Berlin : de Gruyter, pp. 506-569.

Comrie, B. 1976. Aspect, Cambridge : Cambridge University Press.

Comrie, B. 1981. Language universals and linguistic typology, Oxford : Blackwell.

Comrie, B. 1985. Tense, Cambridge : Cambridge University Press.

Culioli, A. 1990. Pour une linguistique de l'énonciation, Paris : Ophrys.

Culioli, A. 1995. Cognition and Representation in Linguistic Theory. Texts selected, edited and introduced by M. Liddle, Current Issues in Linguistic Theory 112, Amsterdam / Philadelphia : John Benjamins.

Edelman, G. 1992. Bright air, brilliant fire : on the matter of mind, New-York : Basic Books.

Epstein, S. \& al. 1996. Introduction. In W. Abraham \& al. (eds.), Minimal ideas : syntactic studies in the minimalist framework, Amsterdam / Philadelphia : Benjamins, pp. 1-66.

Fodor, J. 1975. The language of thought, Cambridge Mass. : Harvard University Press.

Fodor, J. 1983. Modularity of mind, Cambridge Mass. : MIT Press.

Fuchs, C. 1993. Linguistique, sciences du langage et construction du sens en contexte : le traitement de l'ambiguïté. In F. Eustache \& B. Lechevalier (eds.), Langage et aphasie, Bruxelles : De Boeck, pp. 267-289.

Fuchs, C. 1994a. Paraphrase et énonciation, Paris / Gap : Ophrys.

Fuchs, C. 1994b. The challenges of continuity for a linguistic approach to semantics. In C. Fuchs \& B. Victorri (eds.), Continuity in linguistic semantics, Amsterdam / Philadelphia : Ben,jamins, pp. 93-107.

Fuchs, C. \& al. 1993. Linguistique et traitements automatiques des langues, Paris : Hachette.

Fuchs, C. \& B. Victorri (eds.). 1994. Continuity in linguistic semantics, Amsterdam / Philadelphia : Benjamins.

Greenberg, J. 1963. Some universals of grammar with particular reference to the order of meaningful elements. Universals of language, Cambridge Mass. : MIT Press, pp. 58-90.

Greenberg, J. 1966. Language universals. With special reference to feature hierarchies, La Haye / Paris : Mouton.

Greenberg, J. 1973. The typological method. In T. Sebeok (ed.), Current issues in linguistics, La Haye / Paris : Mouton, pp. 149-194.

Greenberg, J. 1974. Language typology (a historical and analytic overview), La Haye / Paris : Mouton.

Gross, M. \& A. Lentin. 1967. Notions sur les grammaires formelles, Paris : Gauthier-Villars.

Guillaume, G. 1969. Langage et science du langage, Paris : Nizet.

Hockett, Ch. 1954. Chinese versus English : an exploration of the Whorfian thesis. In H. Hoijer (ed.), Language in culture, Chicago : University of Chicago Press, pp. 106-123.

Jackendoff, R. 1987. Consciousness and the computational mind, Cambridge Mass. : MIT Press.

Jackendoff, R. 1996. How language helps us think. Pragmatics and cognition, 4 : 1, Amsterdam : Benjamins, pp. 1-34

Joseph, J. 1996. The immediate sources of the "Sapir-Whorf hypothesis". Historiographia Linguistica, $23: 3$, Amsterdam : Benjamins.

Lakoff, G. 1987. Women, fire and dangerous things : what categories reveal about the mind, Chicago : University of Chicago Press.

Langacker, R. 1987 / 1991. Foundations of cognitive grammars, Stanford : Stanford University Press ; vol. I : "Theoretical prerequisites" vol. II : "Descriptive application".

Lazard, G. 1981. La quête des universaux sémantiques en linguistique. Bulletin du groupe de recherches sémiolinguistiques, Paris : EHESS \& INALF, IV : 19, pp. 26-37. 
Lazard, G. 1992. Y a-t-il des catégories interlangagières ?. In S. Anschütz (ed.), Texte, Sätze, Wörter and Moneme Heidelberg: Heidelberger Orientverlag, pp. 427-434.

Lee, P. 1996. The Whorf theory complex : a critical reconstruction, Amsterdam / Philadelphia : Benjamins.

Linguistic Typology, Berlin / New-York : Mouton - de Gruyter (vol. 1 : 1997).

Lucy, J. 1992. Language diversity and thought : a reformulation of the linguistic relativity hypothesis, Cambridge : Cambridge University Press.

Martinet, A. 1960. Eléments de linguistique générale, Paris : Colin (4⿳亠̀ éd. : 1964).

Nuyts, J. 1996. Consciousness in language. Pragmatics and cognition, $4: 1$, Amsterdam :Benjamins, pp. 153-180.

Pinker, S. 1994. The language instinct, New-York : Morrow.

Sapir, E. 1924. The grammarian and his language, American Mercury, 1, pp. 149-155. Repris dans E. Sapir. 1949. Selected writings of Edward Sapir in language, culture and personality, Berkeley : University of California Press, pp. 150-159.

Schultz, E. 1990. Dialogue at the margins : Whorf, Bakhtin, and linguistic relativity, Madison : University of Wisconsin Press.

Searle, J. 1992. The rediscovery of mind, Cambridge Mass. : MIT Press.

Seiler, H. 1994. Continuum in cognition and continuum in language. In C. Fuchs \& B. Victorri (eds.), Continuity in linguistic semantics, Amsterdam : Benjamins, pp. 33-43.

Seiler, H. \& Brettschneider (eds.) 1985). Language invariants and mental operations, Tübingen : Narr.

Talmy, L. 1988. Force dynamics in language and cognition. Cognitive Science, $9: 1$.

Vennemann, T. 1972. Topics, subjects and word order : from SXV to SVX via TVX. In Anderson-Jones (ed.), Historical linguistics, Amsterdam : North Holland, pp. 339-377.

Victorri, B. \& C. Fuchs. 1996 : La polysémie : construction dynamique du sens, Paris : Hermès.

Whorf, B. 1940a. Science and linguistics. Technology Review, 42, pp. 229-231 et 247-248. Repris dans B. Whorf. 1956. Language, thought and reality : selected writings by Benjamin Lee Whorf, Cambridge Mass. : MIT Press, pp. 207-219. Trad. fr. : Science et linguistique. In B. Whorf. 1956. Linguistique et anthropologie, Paris : Denoël, pp. 121140 .

Whorf, B. 1940b. Linguistics as an exact science. Technology Review, 43, 61-63, 81-83. Repris dans B. Whorf. 1956. Language, thought and reality: selected writings by Benjamin Lee Whorf, Cambridge Mass. : MIT Press, pp. 220-232. Trad. fr. : Une science exacte : la linguistique. In B. Whorf. 1956. Linguistique et anthropologie, Paris : Denoël, pp. 141160. 